\title{
Ecological aspects of helminth fauna of Magellanic penguins, Spheniscus magellanicus (aves: Spheniscidae), from the Northern Coast of the State of São Paulo, Brazil
}

\author{
Rezende, GC. ${ }^{a}$, Baldassin, P. ${ }^{b, c *}$, Gallo, $H^{d}{ }^{d}$ and Silva, RJ. ${ }^{a}$ \\ aDepartamento de Parasitologia, Instituto de Biociências, Universidade Estadual Paulista - UNESP, \\ CEP 18618-970, Botucatu, SP, Brazil \\ 'baboratório de Química Orgânica Marinha, Instituto Oceanográfico, Universidade de São Paulo - USP, \\ Praça do Oceanográfico, 191, CEP 05508-900, São Paulo, SP, Brazil \\ 'Instituto Argonauta para a Conservação Costeira e Marinha, Rua Guarani, 835, CEP 11680-000, Ubatuba, SP, Brazil

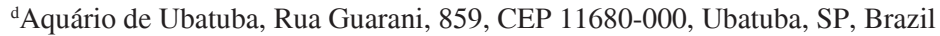 \\ *e-mail: paulets@usp.br
}

Received October 21, 2011 - Accepted March 27, 2012 - Distributed February 28, 2013

\begin{abstract}
The aim of the present study was to evaluate the helminth fauna found in the Magellanic penguin, Spheniscus magellanicus, relating parasite population and community ecological parameters to life aspects of the host species. The study involved 237 specimens of $S$. magellanicus taken from the northern shore of the state of São Paulo (23 $46^{\prime} \mathrm{S}, 45^{\circ} 57^{\prime} \mathrm{W}$ ) and southern shore of the state of Rio de Janeiro (23 $\left.02^{\prime} \mathrm{S}, 44^{\circ} 13^{\prime} \mathrm{W}\right)$, Brazil. The following helminth fauna were found: the nematode Contracaecum pelagicum (core species), found in the stomach; the digenetic Cardiocephaloides physalis and the cestode Tetrabothrius lutzi (satellite species), both collected from the initial portion of the small intestine. Comparisons using the Shannon Diversity Index revealed that the parasite community in juvenile penguins is less diverse in the migratory season than the breeding season. Parasitological studies on penguins and other migratory animals provide important information on species during the time in which they remain pelagic and constitute a useful tool for the acquisition of data that is difficult to obtain through other means, thereby favoring the conservation of the species.
\end{abstract}

Keywords: helminth fauna, ecological parameters, latitudinal variation.

\section{Aspectos ecológicos da helmintofauna de pinguins de Magalhães, Spheniscus magellanicus (Aves: Spheniscidae), do Litoral Norte do Estado de São Paulo, Brasil}

\begin{abstract}
Resumo
Com o intuito de investigar se estudos parasitológicos podem ser utilizados como ferramenta para a conservação de espécies, principalmente migratórias, este trabalho analisa a helmintofauna de Spheniscus magellanicus por meio de parâmetros ecológicos populacionais e da comunidade parasitária, relacionando-os com diversos aspectos de vida da espécie hospedeira. O estudo foi realizado com 237 espécimes de $S$. magellanicus procedentes das praias do litoral norte

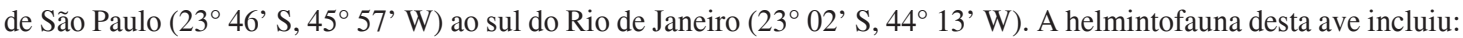
o nematoide Contracaecum pelagicum (espécie-núcleo), encontrado no estômago; o digenético Cardiocephaloides physalis e o cestoide Tetrabothrius lutzi (espécies satélites), ambos coletados na porção inicial do intestino delgado. Comparações utilizando o índice de diversidade de Shannon mostraram que a comunidade de parasitas em filhotes durante o período migratório é menos diversa do que na estação reprodutiva. Os resultados obtidos permitem inferir que estudos parasitológicos em pinguins, assim como em outros animais migratórios, podem fornecer informações importantes a respeito da espécie durante a época em que permanece pelágica, tornando-se uma ferramenta útil na aquisição de informações dificilmente obtidas por outros meios e favorecendo, dessa forma, a conservação da espécie.
\end{abstract}

Palavras-chave: helmintofauna, parâmetros ecológicos, variação latitudinal. 


\section{Introduction}

Migratory animals can provide important information on the environment and are considered key species for conservation. Penguins, in particular, rapidly reflect changes in the marine environment through variations in the population (Boersma, 2008). The Magellanic penguin, Spheniscus magellanicus Forster, 1781, is endemic to South America, with populations distributed along the coast of Patagonia (Argentina and Chile) and the Falkland Islands/ Malvinas, and is the most abundant penguin in temperate areas. This penguin is a top predator in the marine food chain and dependent on this environment for foraging in both the breeding season (October to March), when it performs short daily excursions in search of prey, and the pelagic season (April to September), when it migrates northward to winter on the continental shelf off the coasts of Uruguay and Brazil in order to find the most abundant resources and avoid the adverse environmental conditions found at this time of the year on its breeding grounds (Pazos et al., 2003; Pütz et al., 2007). Another characteristic of this species is its spatial fidelity, as individuals seek the same breeding colony year after year (Boersma, 2008). Spheniscus magellanicus is considered an active predator and its movements are therefore related to the search for foraging areas (Ross, 2008). Flocks that frequent the coast of Brazil come from more northern colonies of the Atlantic, guided by the Falkland/Malvinas current (Sick, 1997; Stokes et al., 1998).

Most studies on the biological and ecological aspects of this species are carried out during the breeding season. However, to ensure the conservation of the Magellanic penguin, knowledge is needed on its temporal and spatial distribution, migratory habits and habitat use (Pütz et al., 2007). This information is difficult to attain, especially for animals with pelagic behavior during months of migration.

The parasite community of a species may reveal important information regarding its biology and ecology. The presence of parasites in a host can affect, even if subtly, its behavior, growth, fecundity and mortality and act as a regulator of population size, thereby influencing the ecosystem as a whole. Parasites also reflect the position of the host in the food chain and provide important information on the trophic interactions of this host, its population structure and both natural and human-induced changes in its environment (Marcogliese, 2004). Thus, parasitological studies on penguins and other migratory animals may indicate seasonal changes in diet and temporal trophic relations during migration, constituting a useful tool in the acquisition of information that is difficult to obtain through other means.

The aim of the present study was to investigate the importance of parasitological studies as a tool for the conservation of species, especially migratory species, through an analysis of the helminth fauna found in $S$. magellanicus using ecological parameters on the parasite population level and community as a whole and relating these parameters to life aspects of the host species.

\section{Material and Methods}

This study was conducted with 237 juvenile specimens of S. magellanicus collected between 2005 and 2009 on beaches of the northern shore of the state of São Paulo $\left(23^{\circ} 46^{\prime} \mathrm{S}, 45^{\circ} 57^{\prime} \mathrm{W}\right)$ and the southern shore of the state of Rio de Janeiro (23 $02^{\prime}$ S, $44^{\circ} 13^{\prime}$ W), Brazil. The birds were found either debilitated or dead and were sent to the Ubatuba Aquarium and Argonaut Institute for Coastal and Marine Conservation. Those that did not survive rehabilitation or were already dead upon collection but in adequate condition underwent necropsy for the collection of helminths from the digestive tract and accessory organs, lungs, kidneys and body cavity.

Nematodes were fixed in AFA solution heated to $60{ }^{\circ} \mathrm{C}$. Trematodes and cestodes were fixed in cold AFA solution under cover slip pressure (Amato et al., 1991). For identification, nematodes were cleared with lactophenol and trematodes and cestodes were stained with carmine and cleared with eugenol (Andrade, 2000; Rey, 2001). For the taxonomic identification, morphometric data were acquired using a computerized image analysis system (Qwin Lite 3.1, Leica), adapted to a microscope (DMLB, Leica). The identification of nematodes was based on Vicente et al. (1995) and Diaz et al. (2010); identification of trematodes was based on Travassos et al. (1969), Yamaguti (1971) and Diaz et al. (2010) and identification of cestodes was based on Schmidt (1986) and Diaz et al. (2010). Voucher helminth species were deposited in the Coleção Helmintológica do Instituto de Biociências (CHIBB), Universidade Estadual Paulista, Botucatu, SP, Brazil.

The definition of the core and satellite species and the calculation of prevalence, mean intensity of infection and mean abundance followed the recommendations proposed by Bush et al. (1997). The dispersion index was calculated to determine the distribution pattern of the helminth species in the host sample (Krebs, 1999). For comparisons between parasite communities, the Shannon Diversity Index (H'), richness (S) and evenness (E) of the species were calculated based on the method described by Magurran (1988). The Z-test was used to compare the prevalence of helminths found in the present study with values reported in previous studies (Pazos et al., 2003; Diaz and Pazos, 2004; Diaz, 2006).

\section{Results}

Among the 237 juvenile specimens of $S$. magellanicus studied, 118 were infected with at least one species of helminth (overall prevalence: $49.8 \%$ ). The helminth fauna of this penguin included the nematode Contracaecum pelagicum (Johnston and Mawson, 1942), found in the stomach, the digenetic Cardiocephaloides physalis (Lutz, 1926) and the cestode Tetrabothrius lutzi Parona, 1901 , both collected from the initial portion of the small intestine (Table 1).

Contracaecum pelagicum was the most prevalent (49.4\%) and abundant ( $23 \pm 2.8$ helminths/host) helminth and was classified as the core species. Cardiocephaloides 
Table 1. Prevalence (P), mean intensity of infection (MII), mean abundance (MA) and dispersion index (DI) of helminth parasites of Spheniscus magelanicus collected on beaches of the northern shore of the State of São Paulo and the southern shore of the State of Rio de Janeiro, Brazil.

\begin{tabular}{|c|c|c|c|c|c|c|c|}
\hline Helminths & $\mathbf{N}$ & $\mathbf{P}(\%)$ & MII* & CI-MII & MA* & CI-MA & DI \\
\hline $\begin{array}{l}\text { Contracaecum pelagicum } \\
\text { CHIBB 5135-5139 }\end{array}$ & 5457 & 49,4 & $\begin{array}{l}46.6 \pm 4.0 \\
(1-259)\end{array}$ & $38.6-54.7$ & $\begin{array}{c}23.0 \pm 2.8 \\
(0-259)\end{array}$ & $18.1-28.0$ & 64.9 \\
\hline $\begin{array}{l}\text { Cardiocephaloides physalis } \\
\text { CHIBB } 5140\end{array}$ & 776 & 22,4 & $\begin{array}{c}14.6 \pm 2.1 \\
(1-113)\end{array}$ & $9.0-20.3$ & $\begin{array}{l}3.3 \pm 1.1 \\
(0-113)\end{array}$ & $1.8-4.7$ & 39.8 \\
\hline $\begin{array}{l}\text { Tetrabothrius lutzi } \\
\text { CHIBB } 5141\end{array}$ & 799 & 26,6 & $\begin{array}{c}12.7 \pm 1.8 \\
(1-108)\end{array}$ & $8.1-17.3$ & $\begin{array}{c}3.4 \pm 0.9 \\
(0-108)\end{array}$ & $2.0-4.8$ & 35.6 \\
\hline
\end{tabular}

CHIBB Accession number of voucher species in Coleção Helmintológica of the Instituto de Biociências, Universidade Estadual Paulista; N, total number of parasites; CI, confidence interval (95\%); *values represent mean \pm standard error (range).

physalis $(\mathrm{P}=22.4 \%$ and $\mathrm{MA}=3.3 \pm 1.1$ helminths/host $)$ and T. lutzi $(\mathrm{P}=26.6 \%$ and $\mathrm{MA}=3.4 \pm 0.9$ helminths/ host) were satellite species and were very similar in the ecological indexes calculated for these helminthes. The dispersion index for C. pelagicum, C. physalis and T. lutzi (Table 1) indicated that all species were distributed in an aggregated manner, with $C$. pelagicum the most aggregated. The Shannon Index (H') value was 0.69 (variance: $9 \times 10^{-5}$ ). Species richness and evenness values were 3 and 0.625 , respectively.

\section{Discussion}

All three species of helminth fauna found in $S$. magellanicus in the present study have previously been described for specimens of S. magellanicus found on the Brazilian coast during the migratory season (Parona, 1901; Travassos et al., 1969; Yamaguti, 1961, 1971; Santos, 1984; Vicente et al., 1995; Pazos et al., 2000; Linhares and Di Beneditto, 2005; Garbin et al., 2007; Ederli et al., 2009; Diaz et al., 2010), but constitute new geographic records for the region in question.

The data from this study (taken during the migratory season) were compared data from with other publications on parasites found in S. magellanicus during the breeding season (Pazos et al., 2003; Diaz and Pazos, 2004; Diaz, 2006). The prevalence of $C$. pelagicum in the birds studied during the migratory season was similar to that reported for specimens studied during the breeding season $(\mathrm{p}>0.05)$, but mean intensity and abundance values were visibly lower (Table 2). This difference may be explained by the fact that the hosts in the present study were juveniles, whereas the hosts reported in other studies were mostly adults or juveniles and adults studied together, which hinders comparisons. One may therefore suppose that adults are exposed to a greater variability of paratenic/intermediate hosts for a greater length of time and consume a greater amount of food (Pazos et al., 2003), which likely favors the increase in mean intensity of infection and abundance.

Regarding the species $C$. physalis and T. lutzi, the comparison of the prevalence values in the present study with those reported in the literature (Table 3) demonstrates that the percentage of infected individuals is lower during the migratory season. For $C$. physalis, this variation may
Table 2. Comparison of the prevalence $(\mathrm{P})$, mean intensity of infection (MII) and mean abundance (MA) of Contracaecum pelagicum of Spheniscus magelanicus during the migratory and breeding seasons.

\begin{tabular}{lcccc}
\hline & \multirow{4}{c}{ Contracaecum pelagicum } \\
\cline { 3 - 5 } & & $\mathbf{P}(\%)$ & MII & MA \\
\hline Pazos et al. (2003) $^{\text {BS }}$ & 9 & $56^{\mathrm{a}}$ & 161 & 89 \\
Garbin et al. (2007) $^{\mathrm{BS}}$ & 20 & $40^{\mathrm{a}}$ & 149 & 60 \\
Diaz (2006) $^{\mathrm{BS}}$ & 31 & $67^{\mathrm{a}}$ & 190 & 127 \\
Present study $^{\mathrm{MS}}$ & 237 & $4^{\mathrm{a}}$ & 47 & 23 \\
\hline
\end{tabular}

$\mathrm{N}$, total number of penguins; BS, breeding season; $\mathrm{MS}$, migratory season; prevalence $=$ same letters represent $\mathrm{p}>0.05$ (z-test)

be explained by inferences regarding the infection cycle of the host. The main food item of $S$. magellanicus in more northerly colonies (study sites of the data presented herein) is Engraulis anchoita (Frere et al., 1996; Scolaro et al., 1999). Parasitological studies demonstrate that this fish is an intermediate host for the metacercariae of Cardiocephaloides sp. (Timi et al., 1999; Timi, 2003), which is a parasite found in greater prevalence in populations at latitudes between $40^{\circ} \mathrm{S}$ and $44^{\circ} \mathrm{S}$ in spring, but is completely absent from populations of northern Argentina in autumn. It may be inferred that the low prevalence of C. physalis in the juveniles analyzed in the present study was due to the exposure of these individuals to noninfected E. anchoita during their migration northward in autumn. In contrast, adults feed on these intermediate hosts throughout the breeding season, which coincides with the season and geographic distribution of the metacercariae in this fish population. A similar situation may be associated to the low prevalence of infection by $T$. lutzi (Table 3). However, there are no studies on the intermediate hosts of this species, especially with regard to latitudinal variations and the biological cycle of $S$. magellanicus.

Regarding the mean intensity of infection and mean abundance of $C$. physalis and T. lutzi observed during the migration period, lower values were also found in comparison to those reported in previous studies (Table 3). These findings may also be related to latitudinal variation and the exposure time of the host to the parasites, as mentioned 
Table 3. Comparison of the prevalence (P), mean intensity of infection (MII) and mean abundance (MA) of Cardiocephaloides physalis and Tetrabothrius lutzi of Spheniscus magelanicus during the migratory and breeding seasons.

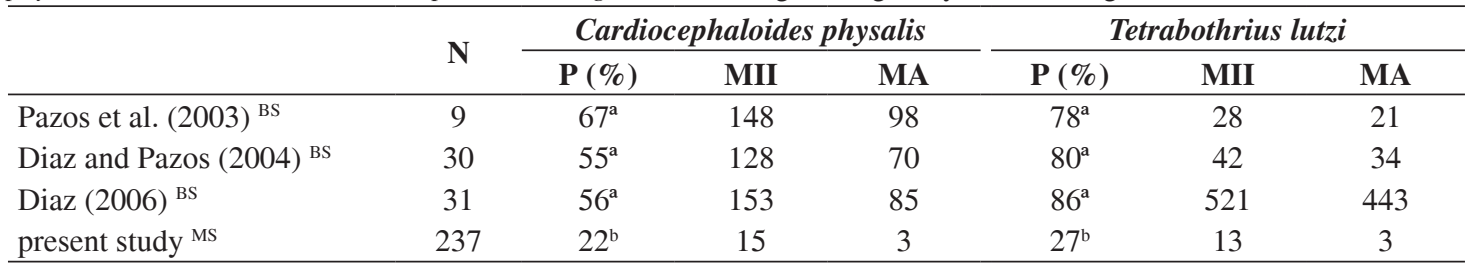

$\mathrm{N}$, total number of penguins; BS, breeding season; MS, migratory season; prevalence $=$ same letters represent $\mathrm{p}>0.05$ and different letters, $\mathrm{p}<0.05$ (z-test).

above. Moreover, the comparative analysis is hindered by the following factors: (1) the expressive difference in the number of individuals sampled; (2) the presentation of data with no discrimination of age; and (3) the absence of information in some studies, such as standard errors or standard deviations of the parameters analyzed.

The Shannon Diversity Index (Magurran, 1988) is restricted to comparative situations and its value was presented in the present study with the aim of comparing the parasite communities of $S$. magellanicus with previously published data. As the individuals analyzed in the present study were juveniles at least one year of age, as determined by the feather coloration pattern, and as Pazos et al. (2003) offers Shannon Diversity Index values for diverse situations, the comparison was made based on values presented for young birds, as the parasite community of this age group more closely resembles that of the juveniles studied here. The statistical analyses revealed significant differences between communities ( $\mathrm{t}=9.997$; $\mathrm{gl}=1313$; $\mathrm{p}<0.001)$. The community of parasites in young birds studied during the nonmigratory season in Argentina is more diverse than that in the juveniles studied during the migratory period in Brazil ( $H^{\prime}=0.93$ versus $\left.H^{\prime}=0.69\right)$. This difference may be understood through a combined analysis of species richness and evenness in each community. The Shannon Index gives greater weight to species richness. The community studied by Pazos et al. (2003) was made up of five distinct species, whereas three species are reported in the present study, resulting in a significant difference in index values. Moreover, the values regarding species evenness reveal that the representativeness of each species in the parasite community studied by Pazos et al. (2003) was less similar.

Diaz and Pazos (2004) reported latitudinal variations in the parasite community of $S$. magellanicus throughout the migratory season and found that penguins from the region of Buenos Aires did not have the parasites T. lutzi, $C$. obvelatus or Corynosoma sp., the latter two of which were also not found in the penguins on the Brazilian coast. As parasites with a heteroxenous life cycle show some degree of specificity in relation to their intermediate hosts, the occurrence of such parasites in a definitive host indicates predator-prey interactions (Marcogliese, 2004). One may therefore suppose that latitudinal variations in the parasite community are caused by a change in the composition of the diet of the penguins as a result of migration.
Due to its pelagic behavior during the months of migration, studies on S. magellanicus outside its breeding grounds are limited to the occasional appearance on beaches. This appearance is generally explained by the irregular movements of errant individuals or those splitting from the flock as a result of population overcrowding or a scarcity of food sources (Ross, 2008), as demonstrated by the totality of juveniles in the records of occurrence on beaches.

The above-cited aspects demonstrate that studies on the diet of S. magellanicus in regions of its occurrence during the winter migration may offer distorted results regarding the feeding preferences of the species, since these studies involve individuals that are physically debilitated, likely due to feeding inefficiency. However, although latitudinal variations in dietary items for $S$. magellanicus indicate that its foraging behavior is opportunistic (Frere et al., 1996), its feeding preference appears to be stable over time in different areas (Scolaro et al., 1999). Studies carried out in Brazil report a greater frequency of traces of cephalopods in the stomachs of juveniles that reach the beaches (Fonseca et al., 2001; Linhares and Di Beneditto, 2005; Pinto et al., 2007; Baldassin et al., 2010). However, as prey with less energy value (Frere et al., 1996), the preference for this item is uncertain and may be explained by the lack of fish in particular feeding grounds and/ or the season of the year or by the overestimation of cephalopods in the diet due to the retention of the beak in the gastrointestinal tract for a longer time in comparison to the digestion of fish. Nonetheless, one cannot discard the importance of cephalopods to $S$. magellanicus on the Brazilian coast. In addition, the increase in the consumption of cephalopods instead of fish may account for the decrease in the abundance of helminthes infecting S. magellanicus during the migration season.

The ecological analyses presented lead one to conclude that, as proposed by Marcogliese (2004), parasites play a crucial role in the study of populations of host species. A study that offers long-term data is capable of revealing interactions that were previously considered uncommon in the parasite-host relationship. From a comparative analysis of some data, one may infer the position of the host in the food chain and the trophic relations necessary so that a parasite in the larval stage in an intermediate host can reach its definitive host. 
Timi et al. (1999) report the occurrence of Cardiocephaloides sp. metacercariae in the eyes of E. anchoita. Contracaecum spp. are included in the family Anisakidae and are parasites of aquatic organisms such as fish, marine mammals and piscivorous birds (Bicudo et al., 2005). The transmission of anisakids usually involves aquatic invertebrates and fish as intermediate or paratenic hosts (Anderson, 2000). The larval stage is commonly found in fish and adult worms are found in the intestine of piscivorous birds and mammals (Moravec, 1998). In fact, the occurrence of third-stage larvae of Contracaecum sp. infecting the marine fish E. anchoita (Timi et al., 2001) as well as nototheniid fish from the South Shetland Islands (Elephant Island, Shishkov Island and King George Island in Admiralty Bay) (Rokicki et al., 2009) has previously been demonstrated. Moreover, the life cycle of Tetrabothrius sp. may also involve nototheniid fishes as second intermediate or paratenic hosts (Hoberg, 1987).

Accordingly, since the distribute patterns of marine parasites in a single host species are mainly determined by the temperature-salinity relation and its association to specific masses of water and parasites with an indirect life cycle depend on the presence of available hosts for their development stages, it is possible to use these data to determine the diet, migratory routes and foraging areas of a species, as in studies that use parasites as biological markers of populations of marine organisms (Williams et al., 1992, MacKenzie, 2002; Timi, 2003; Timi, 2007).

The richness of the parasite community of a given species likely denotes a greater number of trophic interactions for the species. The present study found a small helminth community infecting S. magellanicus and demonstrated a change in dietary items during the migration season. Thus, parasitological, ecological and behavioral studies involving a larger number of species from the food chain related to a particular definitive host can be used as a tool for the conservation of species, especially migratory species, as well as the ecosystem in which these species are found.

Acknowledgements - The authors are grateful to Max Rondon Werneck for his critical reading of the manuscript and the Brazilian fostering agency Fundação de Amparo à Pesquisa do Estado de São Paulo - FAPESP (Processo 2008/57430 - 9 and 2010/07227-2) for the grant provided.

\section{References}

AMATO, JFR., BOEGER, WA. and AMATO, SB., 1991. Protocolos para laboratório - Coleta e processamento de parasitos de pescado. Rio de Janeiro: Imprensa Universitária UFRRJ. 81 p.

ANDERSON, RC., 2000. Nematode parasites of vertebrates: their development and transmission. 2nd ed. New York: CABI Publishing. $650 \mathrm{p}$.

ANDRADE, CM., 2000. Meios e soluções comumente empregados em laboratórios. Rio de Janeiro: Editora Universidade Rural. 353 p.

BALDASSIN, P., SANTOS, RA., CUNHA, JMM., WERNECK, MR. and GALLO, H., 2010. Cephalopods in the diet of Magellanic penguins (Spheniscus magellanicus, FORSTER, 1781) found on the cost of Brazil. Marine Ornithology, vol. 38, p. 55-57.
BICUDO, AJA., TAVARES, LER. and LUQUE, JL., 2005. Larvas de Anisakidae (Nematoda: Ascaridoidea) parasitas da cabrinha Prionotus punctatus (Bloch, 1793) (Osteichthyes: Triglidae) do litoral do Estado do Rio de Janeiro, Brasil. Revista Brasileira de Parasitologia Veterinária, vol. 14, p. 109-118. PMid:16229755.

BOERSMA, PD., 2008. Penguins as Marine Sentinels. BioScience, vol. 58, no. 7, p. 597-607. http://dx.doi.org/10.1641/B580707

BUSH, AO., LAFFERTY, KD., LOTZ, JM. and SHOSTAK, AW., 1997. Parasitology meets ecology on its terms: Margolis et al. revisited. Journal of Parasitology, vol. 83, p. 575-583.

DIAZ, JI., 2006. Las Comunidades Parasitarias como Expresión de Distinto Comportamiento Trófico en Aves del Mar Argentino. La Plata: Universidad Nacional de La Plata. 258 p. Tesis Doctoral en Ciencias Naturales.

DIAZ, JI., CREMONTE, F. and NAVONE, GT., 2010. Helminths of the Magellanic penguin, Spheniscus magellanicus (Sphenisciformes), during the breeding season in Patagonian coast, Chubut, Argentina. Comparative Parasitology, vol. 77, no. 2, p. 172-177. http:// dx.doi.org/10.1654/4441.1

DIAZ, JI. and PAZOS GE., 2004. Structure of the helminth community of the magellanic penguin: first results from northern Argentinean coast. In Proceedings of the V International Penguin Conference, 2004. Ushuaia. p. 56.

EDERLI, NB., OLIVEIRA, FCR., MONTEIRO, CM., SILVEIRA, LS. and RODRIGUES, MLA., 2009. Ocorrência de Contracaecum pelagicum Johnston \& Mawson, 1942 (Nematoda, Anisakidae), em pinguim-de-magalhães (Spheniscus magellanicus Forster, 1781) (Aves, Spheniscidae) no litoral do Espírito Santo. Arquivo Brasileiro de Medicina Veterinária e Zootecnia, vol. 61, no. 4, p. 1006-1008. http://dx.doi.org/10.1590/S0102-09352009000400034

FONSECA, VSS., PETRY, MV. and JOST, AH., 2001. Diet of the Magellanic Penguin on the Coast of Rio Grande do Sul, Brazil. Waterbirds, vol. 24, no. 2, p. 290-293. http://dx.doi. org/10.2307/1522046

FRERE, E., GANDINI, P. and LICHTSCHEIN, V., 1996. Variación latitudinal en la dieta del pingüino de Magallanes (Spheniscus magellanicus) en la costa patagónica, Argentina. Ornitologia Neotropical, vol. 7, p. 35-41.

GARBIN, LE., NAVONE, GT., DIAZ, JI. and CREMONTE, F., 2007. Further study of Contracaecum pelagicum (nematoda: anisakidae) in Spheniscus magellanicus (Aves: Spheniscidae) from Argentinean coasts. Journal of Parasitology, vol. 93, no. 1, p. 143-150. PMid:17436954. http://dx.doi.org/10.1645/GE-875R1.1

HOBERG, EP., 1987. Tetrabothrius shinni sp. nov. (Eucestoda) from Phalacrocorax atriceps bransfieldensis (Pelecaniformes) in Antarctica with comments on morphological variation, hostparasite biogeography, and evolution. Canadian Journal of Zoology, vol. 65 , n. 12, p. 2969-2975. http://dx.doi.org/10.1139/z87-450

KREBS, CJ., 1999. Ecological Methodology. 2nd ed. Menlo Park: Benjamim, Cummings. 620 p.

LINHARES, MB. and DI BENEDITTO, APM., 2005. Parasitismo e hábito alimentar do pinguim-de-Magalhães (Spheniscus magellanicus Foster 1781) em Arraial do Cabo/RJ. In Proceedings of the VII Congresso de Ecologia do Brasil, 2005. Caxambu.

MacKENZIE, K., 2002. Parasites as biological tags in population studies of marine organisms: an update. Parasitology, vol. 124, Supplement S1, p. 53-63. http://dx.doi.org/10.1017/ S0031182002001518 
MAGURRAN, AE., 1988. Ecological Diversity and Its Measurement. Princeton: Princeton University Press. 179 p.

MARCOGLIESE, DJ., 2004. Parasites: small players with crucial roles in the ecological theater. EcoHealth, vol. 1, no. 2, p. 151-164. http://dx.doi.org/10.1007/s10393-004-0028-3

MORAVEC, F., 1998. Nematodes of freshwater fish of the neotropical region. Praha: Academia. 464 p.

PARONA, C., 1901. Di alcuni cestodi brasiliani reccolti 1dal Dott. Ad. Lutz. Bollettino dei Musei di Zoologia e Anatomia comparata della R. Universita di Genova, no. 102.

PAZOS, GE., LAURENTI, S. and DIAZ, JI., 2000. Nematodes parásitos del pingüino de Magallanes (Spheniscus magellanicus) en una colonia de Península Valdes, Chubut. In Proceedings of the III Congreso Argentino de Parasitología, 2000. Mar del Plata. p. 347.

PAZOS, GE., LAURENTI, S. and DIAZ JI., 2003. Helmintofauna del Pingüino de Magallanes (Spheniscus magellanicus) en Península Valdes, provincia del Chubut. Resultados preliminares. Historia Natural (Segunda Serie), vol. 2, no. 10, p. 85-94.

PINTO, MBLC., SICILIANO, S. and DI BENEDITTO, APM., 2007. Stomach contents of the Magellanic Penguin Spheniscus magellanicus from the northern distribution limit on the Atlantic coast of Brazil. Marine Ornithology, vol. 35, p. 77-78.

PÜTZ, K., SCHIAVINI, A., REY, AR. and LÜTHI BH., 2007. Winter migration of magellanic penguins (Spheniscus magellanicus) from the southernmost distributional range. Marine Biology, vol. 152, p. 1227-1235. http://dx.doi.org/10.1007/s00227-007-0770-5

REY, L., 2001. Parasitologia. 3. ed. Rio de Janeiro: Guanabara Koogan. 856 p.

ROKICKI, J., RODJUK, G., ZDZITOWIECKI, K. and LASKOWSKI, Z., 2009. Larval ascaridoid nematodes (Anisakidae) in fish from the South Shetland Islands (Southern Ocean). Polish Polar Research, vol. 30, no. 1, p. 49-58.

ROSS, AL., 2008. Pingüins-de-Magalhães (Spheniscus magellanicus) no Nordeste: Migrantes ou Errantes? Boletim eletrônico do CEMAVE, vol. 2 , no. 2.

SANTOS, CP., 1984. Um nematódeo parasito do pingüim Spheniscus magellanicus (Forster) (Ascaridoidea, Anisakidae). Memórias do Instituto Oswaldo Cruz, vol. 79, no. 2, p. 233-237. http://dx.doi.org/10.1590/S0074-02761984000200010

SCOLARO, JA., WILSON, RP., LAURENTI, S., KIERSPEL, M., GALLELLI, H. and UPTON, JA., 1999. Feeding preferences of the
Magellanic penguin over its breeding range in Argentina. Waterbirds, vol. 22, no. 1, p. 104-110. http://dx.doi.org/10.2307/1521999

SICK, H., 1997. Ordem Sphenisciformes. In SICK, H. (Eds.). Ornitologia Brasileira. Rio de Janeiro: Ed. Nova Fronteira. p. 186-188.

SCHMIDT, GD., 1986. CRC Handbook of Tapeworm Identification. Boca Raton: CRC Press. 675 p.

STOKES, DL., BOERSMA, PD. and DAVIS, LD., 1998. Satellite tracking of Magellanic Penguin migration. The Condor, vol. 100, no. 2, p. 376-381. http://dx.doi.org/10.2307/1370280

TIMI, JT., 2003. Parasites of Argentine anchovy in the south-west Atlantic: latitudinal patterns and their use for discrimination of host populations. Journal of Fish Biology, vol. 63, p. 90-107. http://dx.doi.org/10.1046/j.1095-8649.2003.00131.x

-, 2007. Parasites as biological tags for stock discrimination in marine fish from South American Atlantic waters. Journal of Helminthology, vol. 81, no. 2, p. 107-11. PMid:17578590. http:// dx.doi.org/10.1017/S0022149X07726561

TIMI, JT., MARTORELLI, SR. and SARDELLA, NH., 1999. Digenetic Trematodes parasitic on Engraulis anchoita (Pisces: Engraulidae) from Argentina and Uruguay. Folia Parasitologica, vol. 46, p. 132-138.

TIMI, JT., SARDELLA, NH. and NAVONE, GT., 2001. Parasitic nematodes of Engraulis anchoita Hubbs et Marini, 1935 (Pisces, Engraulidae) of the Argentine and Uruguayan coasts, South West Atlantic. Acta Parasitologica, vol. 46, no. 3, p. 186-193.

TRAVASSOS, L., FREITAS, T. and KOHN, A., 1969. Trematódeos do Brasil. Memórias do Instituto Oswaldo Cruz, vol. 67, p. 1-755.

VICENTE, JJ., RODRIGUES, HO., GOMES, DC. and PINTO, RM., 1995. Nematóides do Brasil. Parte IV: Nematóides de aves. Revista Brasileira de Zoologia, vol. 10, no. 1, p. 50-214.

WILLIAMS, HH., MacKENZIE, K. and McCARTHY, AM., 1992. Parasites as biological indicators of the population biology, migrations, diet, and phylogenetics of fish. Reviews in Fish Biology and Fisheries, vol. 2, no. 2, p. 144-176. http://dx.doi. org/10.1007/BF00042882

YAMAGUTI, S., 1961. Systema Helminthum - Nematodes. London: Interscience Publishers. vol. 3, part 1-2, 1261 p.

-, 1971. Synopsis of Digenetic Trematodes of Vertebrates. Tokyo: Keigaku Publishing Company. 1074 p. 